\title{
Recollection
}

\section{In memory of Professor Tianqin Cao (Tien-chin Tsao)}

\author{
Youshang Zhang ${ }^{凶}$ \\ Institute of Biochemistry and Cell Biology, Chinese Academy of Sciences, Shanghai 200031, China \\ $\triangle$ Correspondence: zys100@yahoo.com
}

In December this year, the 4th Tianqin Cao Memorial Symposium on Protein Research will be held in Xiamen (Amoy). On this occasion, it is my pleasure to write a recollection in memory of Professor Tianqin Cao. It was rather late when I was able to study in Prof. Cao's laboratory as a graduate student in the Institute of Biochemistry. After graduating from the Department of Chemical Engineering of Zhejiang University in 1948, I could not find a job in a chemical engineering factory; therefore, I changed my profession to biochemistry and worked as an assistant in the Department of Biochemistry of Hunan Yale Medical College. Afterwards, I continued to teach biochemistry in Beijing and Lanzhou for nearly ten years. Though I wished to do some biochemical research in this medical college, yet I did not have enough time and working facilities. I knew that the Chinese Academy of Sciences (CAS) had a famous institute in Shanghai, the Institute of Physiology and Biochemistry. I wished someday I would be able to study biochemistry there. My dream did not come true until 1957, when people could freely participate the graduate student entrance examination of CAS without the approval of their affiliated institutions. Fortunately, I passed the examination of the Institute of Physiology and Biochemistry, and eventually became a graduate student of Prof. Cao. Prof. Cao is an amiable scientist, only five years older than I. When I arrived in Shanghai in May 1957 from Lanzhou, Prof. Cao told me that he had been working in Lanzhou in a leather processing factory founded by Rewi Alley during the AntiJapanese War and became interested in leather protein. In Shanghai, he and his student Jiamu Peng also worked on procollagen from rabbit skin along with his major work on muscle protein. In the summer of 1957, the newly arrived graduates and postgraduates must have a 3-month intensive course of advanced biochemistry; and only those who passed the examination were allowed to do research in the laboratory. Studies during these 3 months were very hard, with lectures in the morning and experiments in the afternoon. We enjoyed Prof. Cao's lectures a lot. He usually explained complicated

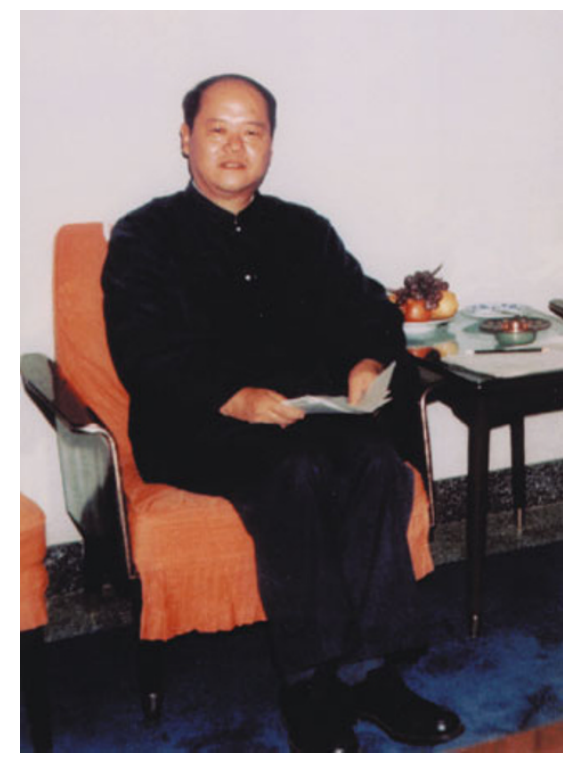

Prof. Tianqin Cao (December 5, 1920 -January 8, 1995)

things with simple words. When he talked about tobacco mosaic virus (TMV), he compared nucleic acid to Juliet and protein to Romeo, both were indispensable. When he taught us alpha-helix in protein and double helix in DNA, he cited what Lao Tze said in Dao De Jing: “玄之又玄, 众妙之门”, which means "intriguing and intriguing, a gate to all mysteries". The "helix" ((螺)旋) in Chinese happens to be homophonic to "intriguing" (玄). His humorous speech deeply impressed us how subtle helix is involved in the living activities.

Under the guidance of Prof. Cao, I started my research on the conformation of tropomyosin in different solvents. Aqueous solution is the native environment of proteins while organic solvent may make protein denatured. However, it was reported that some proteins were still active in organic 
solvent. My results showed that tropomyosin was denatured irreversibly in $67 \%$ chloroethanol and its helical content was slightly increased. Years later when I worked on TMV, I found that in $67 \%$ chloroethanol, TMV was degraded into RNA and coat protein, which was denatured and depolymerized. The denatured coat protein was insoluble in aqueous solution. Intriguingly, when denatured coat protein was treated with $33 \%$ acetic acid, it was renatured, since it was soluble in aqueous solution and polymerized to rod form. In 1958, when the formidable project of insulin synthesis started, Prof. Cao's project of muscle protein was suspended. My work was also shifted from tropomyosin to the recombination of native insulin from its two chains. In 1961, I finished my postgraduate studies and obtained a CAS diploma signed by President Moruo Guo.

Biochemistry is an experimental science, and doing experiments is important in postgraduate studies. The first lesson I learned from Prof. Cao was how to kill a rabbit. What he did was to grasp the hind legs of the rabbit, hit its head, cut its carotid and evacuate the blood. I was deeply impressed with his swift and smart action. He also taught how to use the micro electrophoresis apparatus, which was needed to judge the purity of protein preparation. A horizontal viscometer was designed by him made by the machine shop. He also helped me to assemble a light scattering apparatus to measure the size and shape of protein molecules. Sophisticated instruments, like Tiselius electrophoresis apparatus, ultracentrifuge and electron microscope were operated and maintained by some experienced workers. Prof. Cao had paid special attention to equip his laboratory with experimental facilities, and called them "machine tools", which were essential to generating data for various research projects. Jiamu Peng, Jiaxiu Pan and Meixuan Ren had played important parts in this respect.

Before I studied in Prof. Cao's laboratory, I knew very little about his family. I did not even know that his wife was Prof. Xide Xie, whom I knew long ago. Prof. Cao graduated from Yenching University in 1944. From 1944 to 1946, he worked with Joseph Needham in Chongqing at the Sino-British Cooperation Office to help investigate the development of science and education in China. In December 1944, Prof. Cao accompanied Joseph and, Dorothy Needham, and Lawrence Picken to visit Zhejiang University in Zunyi and Meitan. In Meitan, Joseph Needham gave a lecture entitled "Science and Democracy". At that time I was studying chemical engineering in Zunyi, so I did not meet Prof. Cao. In 1946, Prof. Cao went to Cambridge on a British Council Scholarship to study in Kenneth Bailey's laboratory with the recommendation of Joseph Needham. He obtained his Ph.D. in 1951 and was elected a fellow of Gonville and Cauis College, which was unusual for a non-British person. In May 1952, Prof. Xide Xie got her visa with the help of Joseph Needham and arrived in Cambridge from USA to join Prof. Cao, and they were soon married. At that time, my sister Youduan Zhang and her husband Ruiming Chen were also studying in Cambridge and witnessed their wedding. In August 1952, the newly married couple eventually came back to the motherland after travelling about one month from Southampton to Shanghai via Hong Kong.

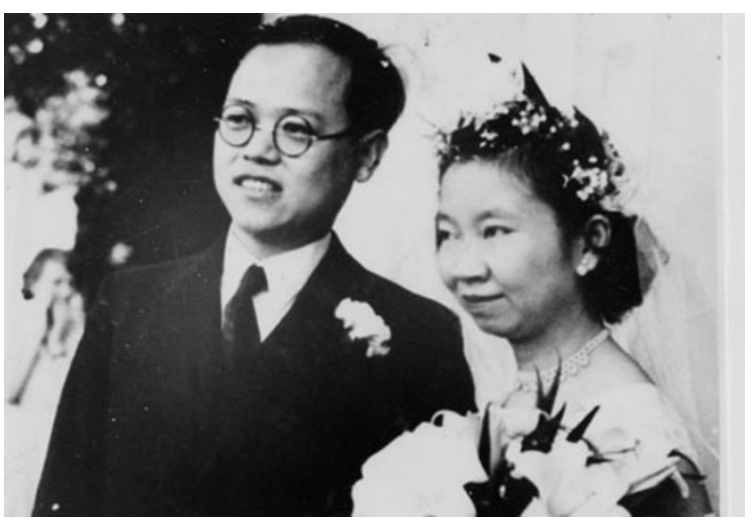

Just married

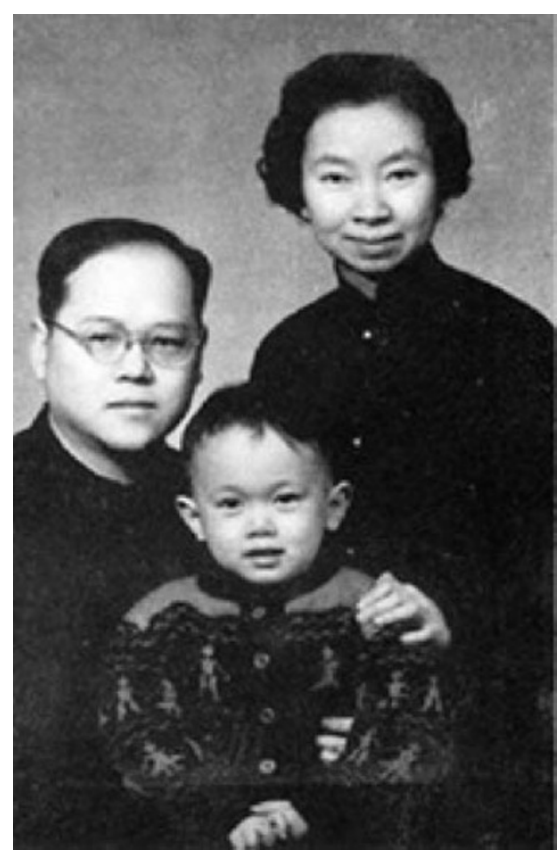

Family photo taken in 1950 s

Prof. Xie had been physically weak since her childhood. During the war, she got tuberculosis and fled to Guiyang where the Hunan Yale Medical College was in exile. A tuberculosis sanatorium was available in the campus for the ailing medical students. Prof. Xie stayed there for a period before she entered Xiamen University. I still remember that I visited her at the sanatorium. In 1964, I was fortunate to study in MRC Laboratory of Molecular Biology at Cambridge through the recommendation of Director Yinglai Wang and 
Prof. Cao. At that time, I was the only one studying in Cambridge from mainland China. Before I went to Cambridge, the Charge d'Affair Xianghui Xiong told me that Joseph Needham was a good friend of Chinese people and I could ask him for help when needed. During my stay in Cambridge, Joseph Needham invited me to dinner in his college. After I came back to China in 1966, the "Cultural Revolution" started and Needham was accused to be a spy, and Prof. Cao and I were persecuted. In the institute, the persecution to Prof. Cao was the cruelest and the most long-lasting. The sequela of persecution led to his untimely passing away.

In Cambridge, Prof. Cao performed systematic studies on muscle proteins, including myosin, tropomyosin and actin. His most important contribution was the discovery of a small subunit of myosin, known as myosin light chain. After coming back to Shanghai, he continued to work productively on muscle proteins in collaboration with his students, the most important being their pioneering electron microscopic studies of tropomyosin and paramyosin paracrystals. In 1978, Prof. Cao was awarded a prize of important scientific achievement by the National Science Congress in recognition of his research on muscle proteins. Here, we should not forget that Prof. Cao was an active advocator and a chief organizer for the total synthesis of insulin, while his name was not included in the author list of the published papers. At the Institute of Biochemistry, Prof. Cao had educated many graduate students and postgraduates. He also taught protein chemistry in Fudan University and Shanghai University of Science and Technology. Prof. Cao's major interest was on muscle proteins, but he was also interested in other protein systems. When his students wished to study some other proteins, he always supported them without hesitation. For instance, after my graduate studies, I became interested in plant viruses. He not only let me start working freely, but also helped me to collaborate with the Institute of Microbiology in Beijing through his connection with Prof. Jiazhi Zhou, who used to study plant pathology in England. I and Meiyun Pei from the Institute of Microbiology did comparative studies on different strains of TMV isolated from Prof. Zhou's laboratory and identified a new strain with special characteristics. This collaborative work marked the earliest molecular biology studies of plant viruses in China. Afterwards, Jiamu Peng and Zuxun Gong worked on plant viruses as well and extended the research to viruses and mycoplasmas infecting important crops. Similarly, Zhengwu Qi first studied actin with Prof. Cao, but later switched his research to proteases and protease inhibitors, on which he has been studying continually.

Prof. Cao had devoted his whole life to the development of protein research in China. Now, I am glad to know that the National Development and Reform Commission has chosen protein research as a key project with unprecedented support. I firmly believe that the new generation of researchers will follow Prof. Cao's career and push forward rapidly the protein research in China.

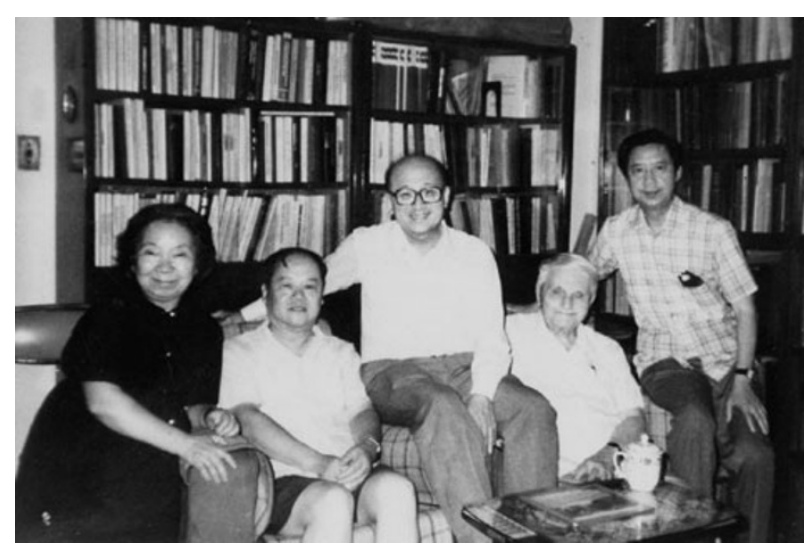

Prof. Cao with Joseph Needham and old friends at home 